\title{
Bacteriostatic and bactericidal actions of boric acid against bacteria and fungi commonly found in urine
}

\author{
P D Meers, C K Chow
}

\begin{abstract}
Boric acid has been used for over 20 years to preserve urine while in transit for bacteriological examination. It has been suggested that it may be toxic for some urinary pathogens. To investigate this several strains of bacteria and fungi commonly found in urine were exposed to different concentrations of boric acid in nutrient broth. Viable counts were made at the outset and at intervals for up to 24 hours at room temperature to detect bacteriostatic or bactericidal effects. At concentrations between 10 and $20 \mathrm{~g} / 1$ boric acid was bacteriostatic or fungistatic for very nearly all the common urinary pathogens. At $10 \mathrm{~g} / 1$ boric acid was weakly bactericidal for some strains of Acinetobacter calcoaceticus and Pseudomonas aeruginosa, though higher concentrations were bacteriostatic only. Group B streptococci varied in their response to boric acid, but for most of them 10 or $20 \mathrm{~g} / 1$ was satisfactorily bacteriostatic. It is concluded that boric acid is rarely toxic, and when it is, the effect is usually sufficiently delayed to be of only theoretical importance.
\end{abstract}

In 1969 Porter and Brodie described the use of boric acid at a concentration of $18 \mathrm{~g} / 1$ to preserve urine while in transit for bacteriological examination. ${ }^{1}$ Although urine is a culture medium, they showed that when boric acid was added the number of any bacteria present did not change significantly for up to 48 hours at room temperature, and other cellular elements remained substantially intact. They claimed this effective bacteriostasis allowed the numerical criteria ${ }^{2}$ for the laboratory diagnosis of urinary tract infection (UTI) to be applied despite delay in performing the examination. This cheap and simple way to increase accuracy in the diagnosis of bacteriuria and pyuria has not been widely adopted. Ten years after the introduction of boric acid for the preservation of urine only a quarter of a group of 64 laboratories in England and Wales were using it. ${ }^{4}$

The relative lack of interest is perhaps explained by the small number of publications that describe the use of boric acid, and the suggestion in some of them that it is occasionally bactericidal. ${ }^{5-8}$ As toxicity and concentra- tion are usually related and as we could find no adequate documentation for the choice of the 18 or $20 \mathrm{~g} / \mathrm{l}$ concentration normally used, we exposed several strains of bacteria and fungi commonly found in urine to different concentrations of the acid in nutrient broth.

\section{Methods}

The culture media used were brain heart infusion (BHI) broth, cystine, lactose, electrolyte deficient (CLED) agar, and 5\% horse blood agar. Dilutions of bacteria were made in quarter strength Ringer's solution (CM225, CM301, CM375, BR52 from Oxoid Ltd, Basingstoke, England). The boric acid powder came from $\mathrm{BDH}$ Chemicals Ltd, Poole, England. The bacteria and fungi tested had been isolated from clinical specimens (table). They had been identified by standard methods. ${ }^{910}$ The hospital laboratory in which the organisms were isolated does not receive specimens from sources in the community. Those available for testing had been taken from hospital patients.

Three linked experiments were performed. In the first, 89 sets of six glass bottles containing $10 \mathrm{ml}$ volumes of $\mathrm{BHI}$ with boric acid at concentrations of $0,2 \cdot 5,5,10,20$ and $40 \mathrm{~g} / 1$ were used. At $40 \mathrm{~g} / 1$ boric acid is approaching the limit of solubility in water at room temperature. Each set of bottles was inoculated

Varieties, numbers, and origins of bacteria and fungi tested

\begin{tabular}{|c|c|c|c|}
\hline Bacteria and fungi & $\begin{array}{l}\text { From } \\
\text { urine }\end{array}$ & $\begin{array}{l}\text { From } \\
\text { other } \\
\text { sites }\end{array}$ & Totals \\
\hline \multicolumn{4}{|l|}{ Enterobacteria: } \\
\hline $\begin{array}{l}\text { Escherichia coli } \\
\text { Klebsiella spp } \\
\text { Enterobacter spp } \\
\text { Citrobacter } \mathrm{spp} \\
\text { Proteus mirabilis } \\
\text { Proteus vulgaris } \\
\text { Morganella morganii } \\
\text { Salmonella spp }\end{array}$ & $\begin{array}{r}11 \\
11 \\
8 \\
7 \\
6 \\
\\
3\end{array}$ & $\begin{array}{r}12 \\
10 \\
5 \\
4 \\
7 \\
3 \\
4 \\
7\end{array}$ & $\begin{array}{r}23 \\
21 \\
13 \\
11 \\
13 \\
3 \\
7 \\
7\end{array}$ \\
\hline $\begin{array}{l}\text { Other Gram negative bacteria: } \\
\text { Acinetobacter calcoaceticus } \\
\text { Acinetobacter lwoffi } \\
\text { Pseudomonas aeruginosa }\end{array}$ & $\begin{array}{l}7 \\
2 \\
7\end{array}$ & $\begin{array}{r}7 \\
10\end{array}$ & $\begin{array}{r}14 \\
2 \\
17\end{array}$ \\
\hline $\begin{array}{l}\text { Gram positive cocci: } \\
\text { Staphylococcus aureus } \\
\text { Staphylcoccus epidermidis } \\
\text { Staphyloccus saprophyticus } \\
\text { Streptococci, group B } \\
\text { Streptococci, group D }\end{array}$ & $\begin{array}{l}7 \\
3 \\
2 \\
6 \\
9\end{array}$ & $\begin{array}{r}12 \\
6 \\
6 \\
4\end{array}$ & $\begin{array}{r}19 \\
9 \\
2 \\
12 \\
13\end{array}$ \\
\hline $\begin{array}{l}\text { Other microbes: } \\
\text { Candida albicans }\end{array}$ & & 5 & 5 \\
\hline Totals & 89 & 102 & 191 \\
\hline
\end{tabular}


with a culture of one of the bacteria that had originated in urine (table). The inoculum was prepared from a 24 hour culture in BHI broth of the strain concerned, diluted first to match an opacity standard approaching a viable count of $10^{8} / \mathrm{ml}$. Further dilutions were made in quarter strength Ringer's solution until an inoculum of $100 \mu \mathrm{l}$ added to each bottle contained about $10^{5}$ bacteria, to yield a target initial count in the broth of $10^{4} / \mathrm{ml}$. Immediately after inoculation $10 \mu \mathrm{l}$ of broth from the BHI bottle with no boric acid was spread on to agar, using blood agar for group B streptococci and CLED for the remainder. The plate was incubated at $37^{\circ} \mathrm{C}$ overnight and a colony count made to measure the inoculum. After the sets of bottles had stood on the bench at about $24^{\circ} \mathrm{C}$ for 24 hours viable counts were performed on all of them by the method described. The target viable count and the small transfer volume of $10 \mu \mathrm{l}$ were chosen both to be of relevance in the diagnosis of UTI and to yield adequate sensitivity with easily counted colonies.

The second experiment involved bacteria and fungi originating in specimens other than urine. This was done to show whether the microbes from urine used in the first experiment had been selected by prior exposure to the boric acid, adopted as a preservative following earlier work. ${ }^{8}$ The second experiment was done in the same way as the first, though only the 0 , 10 , and $20 \mathrm{~g} / 1$ concentrations of boric acid were inoculated with each organism. The inoculum for fungi was established by trial and error. Each set of three bottles was duplicated using inocula prepared from BHI broth cultures that had been incubated for four and 24 hours. This was to see if bacteria or fungi in the logarithmic and stationary phases of growth differ in sensitivity to boric acid.

The third experiment involved single strains of Acinetobacter calcoaceticus, Pseudomonas aeruginosa, and Streptococcus group B for which boric acid had proved somewhat toxic at one or more concentrations. Twenty four hour broth cultures of these were used as inocula, as for the first experiment, but subsequent viable counts were made hourly for the first six hours as well as at 24 hours.

For direct comparison the microbial counts observed were standardised to a common base. They were multiplied by a factor derived by dividing the target initial microbial count of $10^{4} / \mathrm{ml}$ by the inoculum actually achieved in each set of bottles, measured in the control broth immediately after inoculation. Confidence limits for the precision of the counts were estimated by plating 20 replicate $10 \mu \mathrm{l}$ volumes from each of four suspensions containing about $10^{4} / \mathrm{ml}$ viable Escherichia coli, Staphylococcus aureus, group B streptococci and Candida albicans, respectively. The factors used to standardise these counts for inclusion in the figure were derived by dividing the $10^{4}$ target by the means of each set of 20 counts.

\section{Results}

Preliminary experiments showed that growth was inhibited when $100 \mu \mathrm{l}$ volumes of broth containing higher concentrations of boric acid were plated on to solid media. They also showed that heavily capsulated strains of Klebsiella spp gave inconsistent viable counts whether or not boric acid was present. The large mucoid colonies these bacteria produce on agar are assumed to arise from microcolonies of varying size that develop in liquid growth media where they are held together by capsular material. Each microcolony, spread out when transferred to a solid surface, produces a single large colony. In such circumstances a colony count underestimates the viable count by a variable and potentially large factor, so only non-mucoid strains were used in the final experiment.

Viable counts standardised to a common base are shown in the figure, which depicts the responses of all the microbes listed in the table to varying concentrations of boric acid. The graphs combine data from the first experiment with those from the second in which the inocula had also been pre-incubated for 24 hours. This accounts for the greater number of points at the $10 \mathrm{~g} / 1$ and $20 \mathrm{~g} / 1$ concentrations. When a comparison was made no difference was noted between strains that had and had not previously been exposed to boric acid. The bars denoting confidence limits were constructed to take account of the fact that each point in the graphs resulted from two independent viable counts. The range observed experimentally was extended by multiplying the standardised values for the highest and lowest value in each case by itself, and dividing the product by the target count of $10^{4}$. Control broths with no boric acid gave confluent growth when they were subcultured after 24 hours at room temperature, indicating counts in excess of $10^{6} / \mathrm{ml}$.

The second experiment yielded two pairs of viable counts for each microbial strain exposed to boric acid initially either in its logarithmic (four hour) or stationary (24 hour) phase of growth, at concentrations of $10 \mathrm{~g} / \mathrm{l}$ and $20 \mathrm{~g} / \mathrm{l}$. The four and 24 hour counts were compared at each concentration by the Wilcoxon signed rank test. As the different enterobacteria responded so similarly they were treated as a group for this purpose. The other organisms were tested within individual genera or species. The closest approach to a significant difference was found with group B streptococci exposed to boric acid at $20 \mathrm{~g} / \mathrm{l}(t=2, \mathrm{p}=0 \cdot 1)$.

In the third experiment bacterial strains selected as being sensitive to boric acid were exposed to it at two concentrations and sequential viable counts made. The first time the count of Ps aeruginosa were observed to fall below the lower confidence limit (to $30 \%$ of the initial count) was after 24 hours exposure at 10 $\mathrm{g} / \mathrm{l}$. When $A$ calcoaceticus was exposed to $10 \mathrm{~g} / 1$ the count began to fall significantly at the fifth hour, and by 24 hours it had been reduced to $13^{\circ}{ }_{0}$ of the initial level. At $20 \mathrm{~g} / 1$ the count had not changed significantly at six hours, but it had fallen to $37 \%$ at 24 hours. Counts of group B streptococci had fallen to $36 \%$ and $42 \%$ of the numbers originally present in $10 \mathrm{~g} / 1$ and 20 $\mathrm{g} / \mathrm{l}$ boric acid by the second hour. Subsequent exposure for up to 24 hours produced no further reduction. 
Dose-response curves of the bacteria and fungi listed in the table against boric acid, at room temperature. Counts are standardised to an inoculum of $10^{4} / \mathrm{ml}$ (dotted lines) at the beginning of exposure. Confidence limits (bars) are derived from replicate counts of representative organisms.

Graph a, Escherichia coli, b, Klebsiella spp;

$c$, Enterobacter and

Citrobacter spp;

d, Proteus, Morganella and Salmonella spp.

e, Pseudomonas aeruginosa -, Candida albicans $o ; f$, Staphylococcus spp; g, Acinetobacter calcoaceticus - $0, A$ lwoffi $-0 ; h$, Streptococcus group $B-$ $\bullet$, group $D-0$.

(⿸丆口
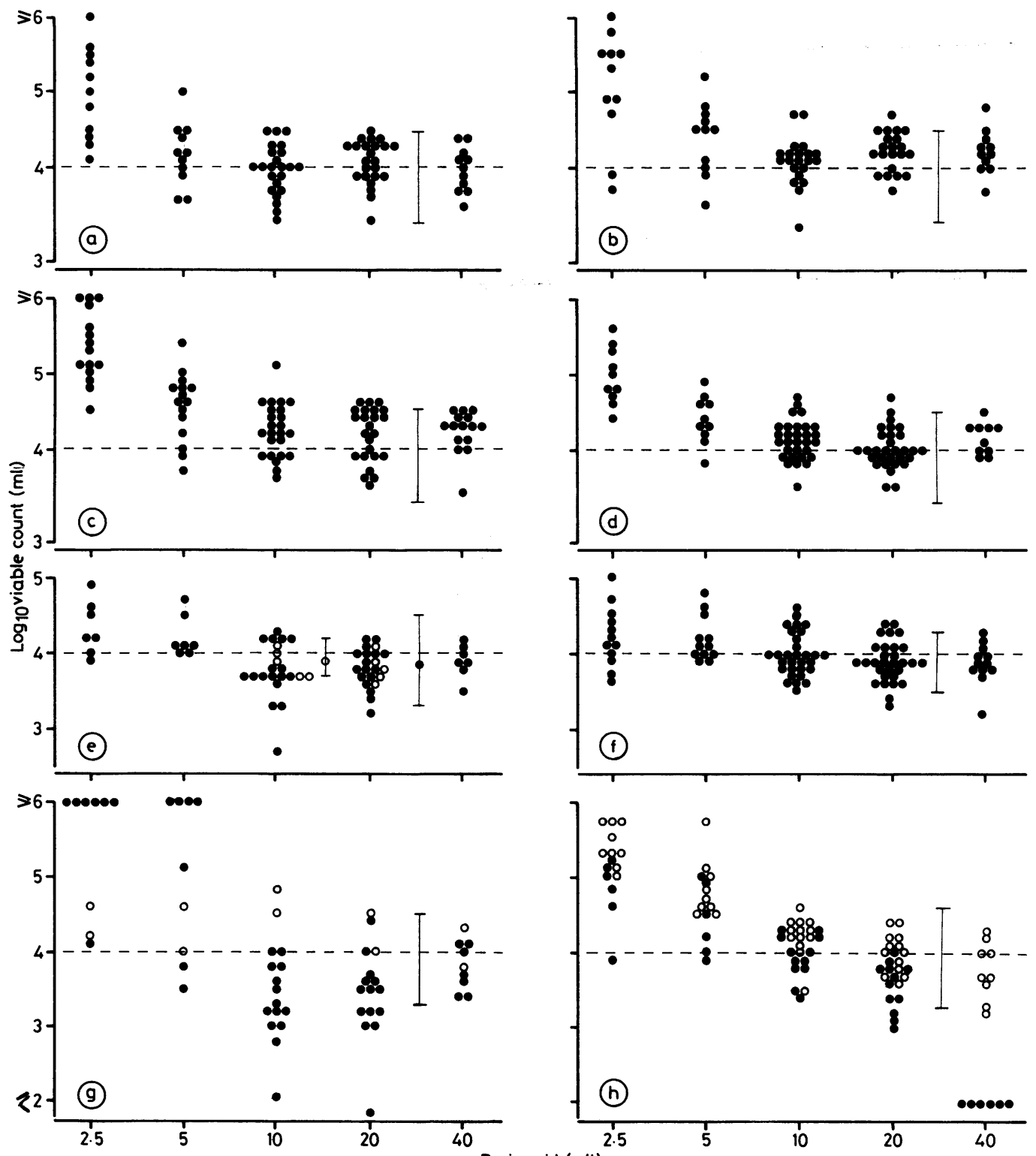

Boric acid $(g / 1)$

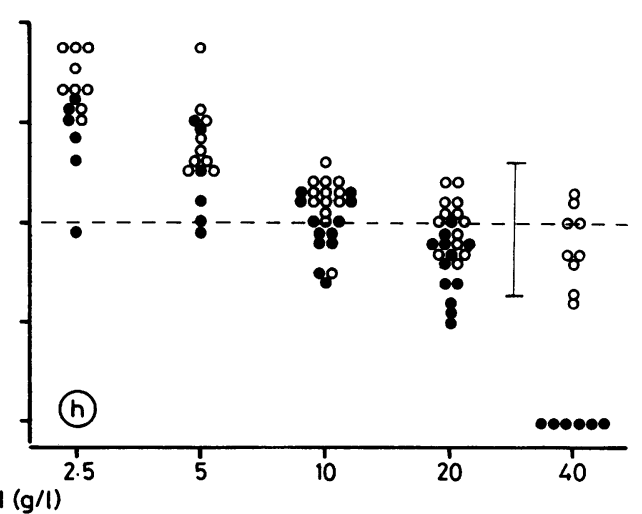

\section{Discussion}

Bacterial multiplication in urine while in transit to the laboratory leads to cumulatively false positive results over time. ${ }^{8}$ Preservation with boric acid, refrigeration, dip-inoculation methods $^{11}$ and limitation of delay before examination have been suggested as ways of overcoming this. Refrigeration can be inconvenient, and its effect is delayed by the time needed for a specimen to cool. It is also not easily applied over a distance. Dip-inoculation methods are popular, but the small surface area provided for interpretation can cause difficulty, particularly with mixed cultures. Their use generally precludes microscopy for the diagnosis of pyuria. Progressive desiccation of agar gels packed in plastic containers leads to an artificial increase in bacterial counts estimated by dip-inoculation, and thus increasing numbers of false positive results. ${ }^{12}$ Preservation with boric acid has none of these disadvantages.

So far as delay before examination is concerned, it has been suggested that no special precautions are necessary if urine is cultured within four hours of its production. ${ }^{13}$ This advice arose from an experiment in which specimens were collected from selected subjects, some of them hospital staff. Patients with glycosuria or urinary tract abnormalities were excluded, and there is no evidence that any of the specimens came from infants, children, or the aged. It might be deduced that the four hour safety margin was assessed on specimens occupying the least heavily contaminated end of the normal spectrum. These would be expected to last longer before they yielded false positive results. In an experiment in which unselected routine clinical specimens were tested the "safe" period was found to be 90 minutes. $^{8}$ This was less than the mean time taken for specimens to reach the laboratory in the hospital concerned, which had a collection service of not less than average efficiency. By the time they were examined unpreserved samples gave $5 \%$ more cultures interpreted as positive than the preserved ones. In these circumstances some method for preventing the multiplication of contaminating bacteria or fungi should be applied to all urine specimens that are sent for bacteriological examination.

We have not found an account of the mechanism by which boric acid acts to produce bacteriostatic or bactericidal effects. Unlike some other antimicrobial substances it is not 
more toxic for rapidly growing than for stationary phase cells. For many microbes exposed for 24 hours, boric acid seems to have a doseresponse curve that is long and nearly flat. This was particularly so for Ps aeruginosa, which displayed almost complete bacteriostasis over the range of boric acid concentrations used for all but one of the 17 strains tested. For the enterobacteria the flat range extended from 10 $\mathrm{g} / 1$ to $40 \mathrm{~g} / \mathrm{l}$, with significant but incomplete bacteriostasis evident at $2.5 \mathrm{~g} / 1$ and $5 \mathrm{~g} / 1$. $A$ lwoffii followed Ps aeruginosa, but most strains of $A$ calcoaceticus were insensitive to boric acid up to $5 \mathrm{~g} / \mathrm{l}$. A partial bactericidal effect for some strains was noted at $10 \mathrm{~g} / \mathrm{l}$, but most higher concentrations were bacteriostatic. It may be that counts of these capsulated bacteria were unreliable for the same reason as suggested for Klebsiella spp.

All the members of the genus Staphylococcus reacted to boric acid much like Ps aeruginosa, but the dose-response curve for streptococci was steeper. Under the conditions of the experiment boric acid was completely bactericidal for group B streptococci at $40 \mathrm{~g} / 1$ and partially so for a few strains at $20 \mathrm{~g} / \mathrm{l}$. Effective bacteriostasis was noted at $10 \mathrm{~g} / 1$ and was incomplete at $5 \mathrm{~g} / 1$ and $2.5 \mathrm{~g} / \mathrm{l}$. Group D streptococci survived well in higher concentrations. Boric acid was fungistatic for $C$ albicans. $S$ saprophyticus was underrepresented in our experiment, as younger women with cystitis rarely present in hospital. The strains that were tested came from the hospital's staff clinic.

It emerges that for nearly all the bacteria and fungi found in urine boric acid is purely bacteriostatic at a range of concentrations between $10 \mathrm{~g} / 1$ and $20 \mathrm{~g} / 1$. In our hands a few strains of group B streptoccci showed a limited bactericidal effect at the concentration generally used and higher concentrations were lethal for all of them. For one of 17 of the strains of Ps aeruginosa, and for perhaps six of 14 of the $A$ calcoaceticus strains tested $10 \mathrm{~g} / 1$ was mildly bactericidal, though for many bacteriostasis was re-established at $20 \mathrm{~g} / 1$.

The results of the third experiment throw light on the practical importance of these indications of toxicity, which in any case involve only a proportion of some less common urinary pathogens. $A$ calcoaceticus is not affected until it has been exposed to boric acid at a concentration of $10 \mathrm{~g} / 1$ for over four hours. At the concentration normally used the small reduction in count seen at 24 hours was not yet evident at six hours. This organism is usually a hospital pathogen, ${ }^{14}$ so specimens containing it should not be subject to long delay before they are examined. With Ps aeruginosa the toxicity observed was restricted to concentrations of boric acid that are lower than usual. From graph $h$ (figure) it can be seen that boric acid was toxic for some group B streptococci at $20 \mathrm{~g} / \mathrm{l}$. When one of these strains was tested in detail the marginal reduction in count was not apparent until the second hour of exposure and it did not then progress. The bactericidal effect was less common at $10 \mathrm{~g} / 1$. These observations show that boric acid is rarely toxic, and suggest that any limited toxicity has little practical relevance because it can often be avoided.

Our results show that although bacteria differ in their sensitivity to it, boric acid at a concentration of $18 \mathrm{~g} / \mathrm{l}$ or $20 \mathrm{~g} / \mathrm{l}$ is a sound choice for the preservation of urine. They also show that in certain circumstances there might be an advantage in using it at $10 \mathrm{~g} / 1$. Unless boric acid is emptied from a collection bottle, overdilution is impossible if the container is designed to be filled nearly to the top. Experience shows that bottles are often incompletely filled, particularly when specimens come from infants, so underdilution is a greater problem. If a bottle is less than half filled a saturated and perhaps toxic concentration may be reached. This danger would be minimised by halving the concentration of boric acid, adding $0.25 \mathrm{~g}$ instead of $0.5 \mathrm{~g}$ to a $25 \mathrm{ml}$ container. Against this must be set the incomplete and delayed paradoxical toxicity of boric acid at $10 \mathrm{~g} / 1$ for a small proportion of some less common urinary pathogens. Alternatively, a smaller bottle containing an appropriately reduced amount of boric acid could be supplied, at least for specimens from infants.

Another advantage of the use of boric acid is that the lower numerical watershed can be adopted to separate positive from negative bacteriological reports. Practice already varies between those who use bacterial counts of $10^{4} / \mathrm{ml}$ or $10^{5} / \mathrm{ml}$ to divide negative from positive, and those who give an equivocal report on speciments with counts between these figures. ${ }^{15}$ There is evidence that preservation with boric acid clarifies the meaning of equivocal $\left(10^{4}-10^{5} / \mathrm{ml}\right)$ counts, making it more likely that they represent true infections. ${ }^{8}$

We suggest that boric acid deserves serious consideration as a general addition to specimen bottles used to transmit urine for bacteriological examination. Toxicity is rare and of theoretical rather than practical concern. The advantages of preservation with boric acid seem to outweigh greatly any disadvantages.

1 Porter IA, Brodie J. Boric acid preservation of urine samples. Br Med J 1969;ii:353-5.

$2 \mathrm{Kass} \mathrm{EH}$. Asymptomatic infections of the urinary tract. Trans Assoc Am Physicians 1956;69:56-64.

$3 \mathrm{Kass}$ EH. Bacteriuria and the diagnosis of infections of the urinary tract. Arch Intern Med 1957;100:709-14.

4 Meers PD. A survey of laboratory methods for the examination of urine. In: Meers PD, ed. The bacteriological examination of urine. London: HMSO, 1978:1-4.

5 Fayinka OA. Boric acid - a useful preservative for urine samples. Afr J Med Sci 1971;2:377-85.

6 Johnston HH, Moss MV, Guthrie GA. The use of boric acid for the preservation of clinical urine specimens. In: Meers PD, ed. The bacteriological examination of urine. London: HMSO, 1978:22-8.

7 Nicklander KK, Shanholtzer CJ, Peterson LR. Urine culture transport tubers: effect of sample volume on bacterial toxicity of the preservative. J Clin Microbiol 1982;15: toxicity

8 Lum KT, Meers PD. Boric acid converts urine into an effective bacteriostatic transport medium. J Infect 1989; 18:51-8.

9 Cowan ST, Steel KG. Manual for the identification of medical bacteria. 2nd ed. Cambridge: Cambridge University Press, 1977.

0 Lennette EH, Balows A, Haustler WJ, Shadomy HJ, eds. Manual of clinical microbiology. 4th ed. Washington: American Society for Microbiology, 1985.

1 Mackey JP, Sandys GH. Laboratory diagnosis of infections of the urinary tract in general practice by means of a dipinoculum transport medium. Br Med J 1965;ii:1286-8.

2 Meers PD, Sandys GH. Dehydration of dip-inoculum outfits. Lancet 1977; i:600.

13 Wheldon BD, Slack M. Multiplication of contaminant bacteria in urine and interpretation of delayed culture.
$J$ Clin Pathol 1977;30:615-9.

14 Bergogne-Berezin E, Joly-Guillou ML, Vieu JF. Epidemiology of nosocomial infections due to AcinetoEpidemiology of nosocomial infections due to Acin
bacter calcoaceticus. $J$ Hosp Infect 1987; 10:105-13.

15 Meers PD. Commentary on the surveys. In: Meers PD, ed. The bacteriological examination of urine. London: HMSO,
1978:12-5. 